\title{
Excursions
}

\author{
Volume 10, Issue 1 (2020) | Chaos
}

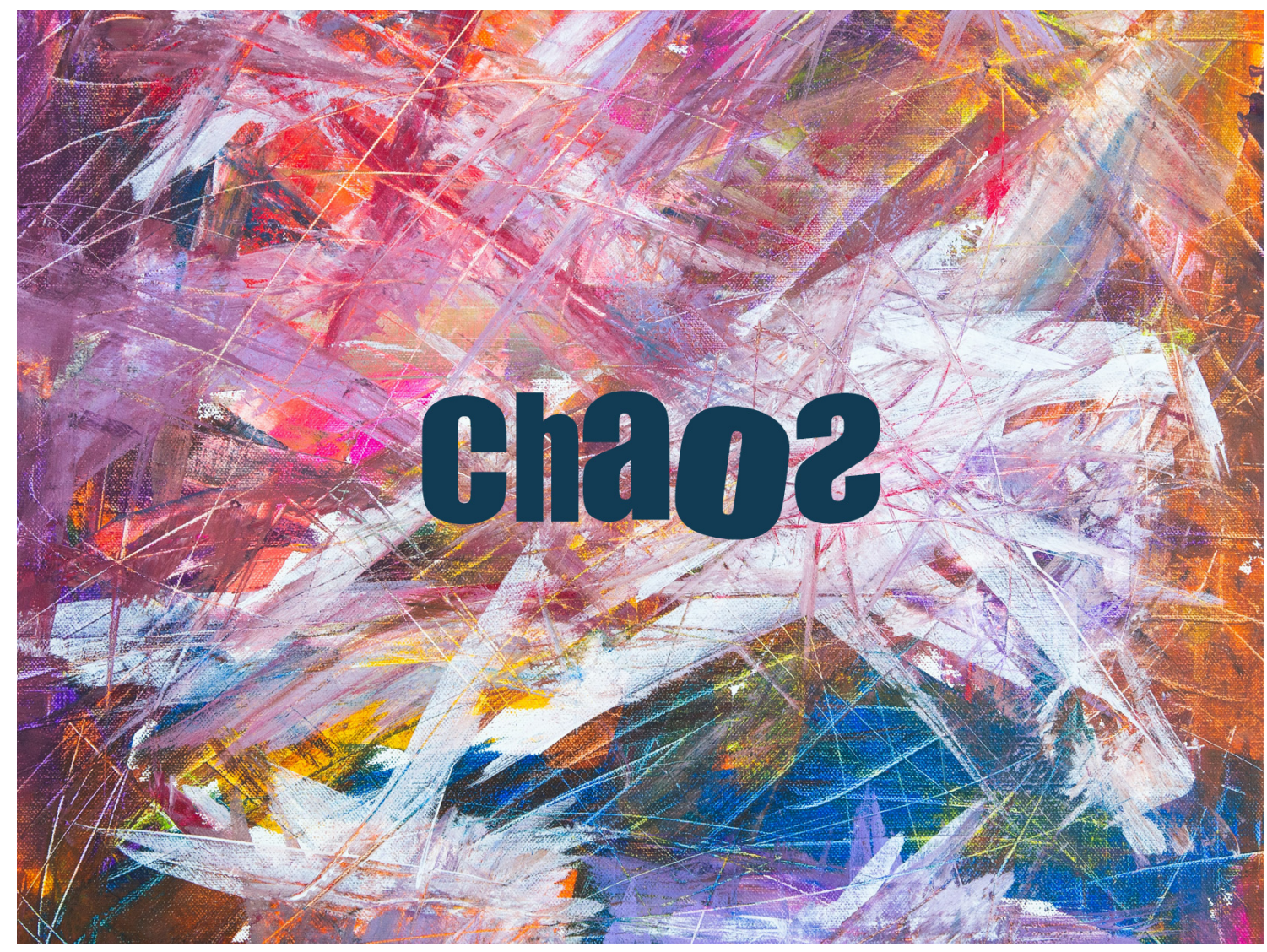

Cover photo: Unbennant \#3 by Felix Spiske | Photo by Markus Spiske on Unsplash

\section{César R. Canova \\ Utopia as a Practical Approach to Urban Chaos: Towards a Meaningful Design Process in Architecture}




\title{
Utopia as a Practical Approach to Urban Chaos: Towards a Meaningful Design Process in Architecture
}

\author{
César R. Canova \\ Universidade de Lisboa
}

[...] utopia and design might together oppose chaos as they can provide an appropriate sense of place and an accurate translation of environmental meaning, explicitly because chaos has no recognisable order unless when partially analysed. Chaos can hardly be developed or imagined with intention. Chaos has no meaning unless when defined as the opposite of order and Architecture can assist the imagination of such order once we establish what a "balanced" architectural practice means.

\section{Introduction}

Chaos refers to a state of disorder. Within urban design practices - such as Architecture - chaos indicates an absence of recognisable spatial rules. In both cases, chaos is not defined by what it is, but rather what it is not. Rubinowicz (2000) argues that geometric order is conditioned by mathematical forms and relationships, while chaos is the opposite of geometric order. In this sense, geometric order is shaped by design and planning (Rubinowicz, 2000). Others corroborate this argument, including Hall (1960), who suggests that plans are essential to avoid complete chaos, while Arnheim (2004) uses sound and colour to oppose randomness and 
organise arrangements. Abusaada and Elshater (2019) compare terms such as anarchy, chaos, randomness, and order to point to an architectural problem in the context of urban chaos, stating that "chaos refers to an imbalance in the performance of tasks and responsibilities" rather than a random response. Two levels of chaos can, thus, be distinguished: (1) when chaos and a lack of order is perceived as a problem to be solved, and (2) when chaos emerges from an imbalanced architectural design process.

At the first level, several factors can lead to a state of chaos including economic, social, and political aspects of the urban context. This is extrinsic to architecture. Once chaos is perceived and addressed within the design process, the first level becomes the starting point or the problem. For it to be a problem of Architecture, it has to be perceived as a problem that can be solved by architects' actions, i.e. by design. The design process can be defined as a process of mediation intrinsic to Architecture once this discipline is understood as an art and non-verbal communication (Donougho, 1987). In this process, both the way the problem is perceived and the methods towards a solution are tasks performed by architects, even if the original problem deals with more than just Architecture. This control - mediated by architects - relates to how meaning is produced and perceived (Barthes, 1993; Broadbent, 1977; Rapoport, 1990).

Meaning is realised from Charles Peirce's semiotics, to which Charles Morris has also contributed. In this sense, it relates to the philosophical understandings of both phenomenology, which differs from Husserl's (Sonesson, 2017), and semiotics, which involves Saussure's semiology (Fidalgo, 1998), itself intrinsically related to a fallibilistic notion of truth (Burch, 2018). Within this phenomenology of architecture - regarding its meanings and its non-verbal communication - imbalanced architects' performances may constitute a lack of appropriate meaning and result in inadequate responses to the aspects of reality first observed as problematic, thus contributing to a (more) chaotic urban scenario. To define the opposite 
of "imbalance" performances, we suggest an analogy between design and utopia. Utopia is addressed in line with Levitas (2017), from which it can also be related to fallibilism. If we are to oppose chaos, both utopia and design need to be comprehended as processes, rather than just blueprints. To this extent, this article initially presents an overview of the design process, from which the problem emerges. We then formulate the problem as a lack of proper meaning, related to both levels of chaos (as motivation to architectural solutions and as a result of imbalanced architectural practices) before the utopian gedankenexperiment (i.e. "thought experiment") is supplemented as a practical approach to urban chaos and builds towards a meaningful design process.

The lack of meaning in the design process

In synthesis, the design process can be understood as a communication cycle with three main parts: to assess the complex problems of communities, to organize the variety of functional connections into a program, and to suggest transformations via one of the countless project possibilities. The design process remains in constant signification, either by recognising a problem (perceived meaning when inhabiting the work of art) or by suggesting a project (intended meaning when conceiving the design). It becomes cyclic, once it develops a) signification - of reality into theoretical concepts and of concepts into designs; and b) re-signification - of newly designed reality into theoretical concepts. When the urban reality is the context for the design process, the built forms and environments can be understood as "physical expressions of the cognitive categories the human mind imposes on the world around it" (Rapoport, 1990, p. 15). We can conclude that objects elicit meanings, and the question becomes how do they activate these meanings? How do they guide these meanings? And what objects work best? (Rapoport, 1990). This proposed analysis must take into account that a building - or any space designed by an architect - becomes a repository of meaning, for it can 
come to be imbued with meaning not originally intended by the author. In any instance, we might agree that new urban designs take part in the urban reality and can contribute either to order (when efficiently communicating meaning) or chaos (when the message is not well defined, suggested, or perceived).

Hillier (2007, p. 150) suggests that the process of defining objects and identifying their repetitions are opposed to chaos, for instance, "the fact that language has words for classes of things... assumes that we know the difference between order and chaos, that is, that we can discern in the objective world structural stabilities which are sufficiently well defined and repetitious". That is precisely what the work of Christopher Alexander dealt with in the 1970 s and what can be derived from Shape Grammars analytical methods (Alexander et al., 2013; Stiny, 1980; Tepavcevic and Stojakovic, 2012). However, while these works can contribute to the physical analysis, "it is particularly difficult to read fixed-feature elements in terms of meaning" (Rapoport, 1990, p. 90). The exclusion of meaning in syntactical and morphological analysis - such as Space Syntax and Analytical Shape Grammars - attest to this difficulty (Hillier, 2007; Netto, 2013; Stiny, 1981)1.

At this point, it is important to notice that the study of meaning in Architecture might contribute to certain confusion, for it often tries to emulate linguistic approaches and the environmental meaning (Krampen, 1991; Rapoport, 1990). Architecture is "polyfunctional and may have several dimensions of meaning" (Nöth, 1995, p. 436). Only a broad understanding of semiotics within a philosophical approach - to which Charles Peirce is the contemporary founder - can include a contribution to the architectural field, provided everything can be a sign (Fidalgo, 1998). In this sense, Krampen (1991, p. 232) states that "the semiotic study of meaning is not confined to verbal meaning and, therefore, investigates other than signs such as are

\footnotetext{
${ }^{1}$ Netto (2013) argues that Space Syntax's strength depends on the superposition of the syntactic structure to the semantic representation.
} 
present in natural and human environments". Rapoport (1990, p. 73) also explores the environmental meaning, and states that "the role of the social setting (or context) is extremely important, since no human behaviour ever occurs outside a social setting”. The challenge of architects regarding meaningful designs is then to understand the environmental meaning of the cognitive categories, translating them into an architectural language.

When applied to the three parts of the design process - problem, program, and project - this challenge includes the need for non-verbal communication. The statement of the architectural problem must include imagination of meaningful configurations, whether using references, drafts, diagrams, or other images, through visual thinking beyond verbal or written language (Arnheim, 1986). The program, on the other hand, has to do with function. It derives from both analysis and suggestions. Activities can be perceived (when analysed) or incited (when suggested) and may be organized by their functional connections. Silva (1998) has also pointed out the inefficient translation of the program into the project. To surpass the limitation of a program as being mainly concerned with function, Portas (1969) suggested the idea of a meta-program. The prefix 'meta' would indicate greater adaptability than in a model and greater specificity than in a type; however, this idea still needs formalizing aspects (Vassão, 2010). In this sense, we can infer that the design process will only succeed when "meaning is not something apart from function but is itself a most important aspect of function" well integrated with the problem and the project (Rapoport, 1990, p. 15). The concept of the project has also been experimented with as a more adaptive tool through the concept of Metadesign suggested by Giaccardi (2003) and Vassão (2010). A similar criticism can be made since both Metaprogram and Metadesign leave out "meaning".

The notion of meaning that lacks in those aspects of the design process is related to the sense of place, as in Carmona et al (2003). By citing 
Punter $^{2}$ and Montgomery3, Carmona et al (2003) state that the physical configuration, the activities, and the meanings constitute the three fundamental elements of a place's identity. "Configuration", "Use" and "Meaning" are also the three dimensions of urban space analysis advised by Kohlsdorf (1986). The "meaning", in these cases, can be understood as the environmental meaning and thus reiterates the importance of context and place to the architectural practice, avoiding the confusion with the linguistic verbal meaning. Given that the sense of place is theoretically attributed to the good quality of designs (Mahfuz, 2004; Pires, 2013), the lack of environmental (or contextual, non-verbal) meaning becomes the main problem with the design process, for a proper response would oppose chaos. The design process should help translate the structural stabilities and fixedfeature elements found in the urban reality into an architectural meaning, whether in the constitution of the problem, in the organisation of the program, or the spatial suggestions of the project. We then suggest an analogy between utopia and the design process to properly imagine environmental meaning in a contextual setting.

The analogy between the Design Process and the imagination of Utopia

The utopian thought process can be correlated to that which has been described as communication in the design process. The utopian gedankenexperiment emerges from a specific place, by recognizing the spatial traits and social organisation that constitute its environmental meanings. It is then developed into an image with suggested transformations translated into a different yet recognisably place. The goal of the elaborated utopia - and design - is to transform the place from which it emerged. Other

\footnotetext{
2 Punter, J. (1991) 'Participation in the design of urban space', Landscape Design, 200, pp. 24-7. 3 Montgomery, J. (1998) 'Making a city: urbanity, vitality and urban design', Journal of Urban Design, 3, pp. 93-116.
} 
levels of analogy between utopia and design can be perceived once we elaborate a definition of utopia. In utopian thought, two images are present: (1) a model (or type), which consists in reproducible spatial traits, and (2) a place (or portrait), by which the particular context is spatially described (Choay, 2007). In both cases, no definition of utopia is possible without spatial features. Similarly, there is no architectural meaning in verbal concepts; they must be translated into a spatial language with the aid of imagination in an experimental way, by signifying via design or (re)construction. As stated at the beginning of this paper, the lack of recognizable spatial rules can serve as one definition of chaos. Those spatial rules - and their chaotic opposition - can be observed in different levels of the urban environment and bestow several causes. When perceived by the designer or the utopian thinker, that chaotic reality becomes specifically oriented towards an opposite: the proposed change.

Utopias, in other words, are a response to chaos for they appear in greater frequency during periods of transition and seasons of great uncertainty ${ }^{4}$ (Pessoa, 2006). Thomas More's Utopia is concomitant to 16th century discoveries; the French Revolution was the background for the utopian works of Boullée (1728-1799) - such as the Isaac Newton Cenotaph (Figure 1, below) - and Ledoux (1736-1806); Fourier (1772-1837) and Godin (1817-1888) suggested utopian solutions to the social issues brought about by the Industrial Revolution; the World Wars of the 2oth century affected the idealist designs of Le Corbusier (1887-1965); and presently, a myriad of Ecotopias respond to the climate crisis (Callenbach, 2004; Downton, 2009). In fact, "a map of the world that does not include Utopia is not worth even glancing at, for it leaves out the one country at which Humanity is always landing" (Wilde, 1891). Within this process, we can infer that chaos is the fundamental seed of utopias.

\footnotetext{
4 Free translation by the author. "Utopias aparecem mais frequentemente em períodos de transição e épocas de grandes incertezas” (Pessoa, 2006, p. 23).
} 


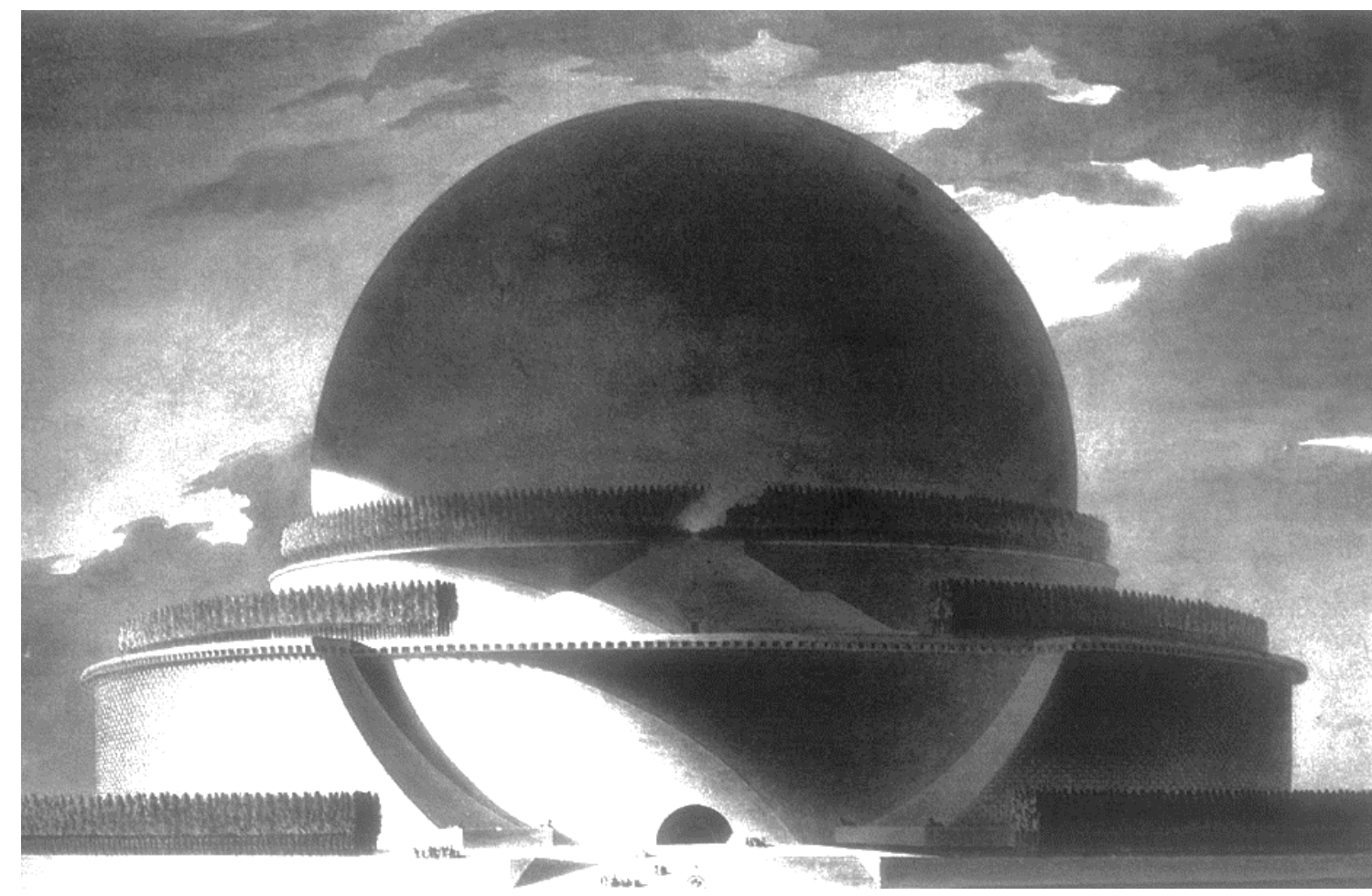

Figure 1: Isaac Newton Cenotaph - Etienne-Louis Boullée. Source: Rubinowicz (2000, p. 200).

Nevertheless, different convictions or beliefs produce divergent attitudes toward utopian thought. Through this consideration, Popper (1986) has pointed out that a utopian blueprint elaborated with a metaphysical goal in the horizon could easily become an ideology, and a pernicious goal would result in a dangerous utopia; the alternative would be to consider practical goals, instead of abstract values that cannot be easily recognised. This solution relates to other concepts such as Ernst Bloch's 'concrete utopia' and Henri Lefebvre's "experimental utopia”, regardless of their similar Marxist backgrounds (Lefebvre, 1961; Münster, 1993). These considerations serve as arguments to a practical approach of utopian speculation, where we can "look not only from the present to the future, but from (potential) future to the present" (Levitas, 2017, p. 7). Although utopias are necessarily characterised by failure, "this is a feature in its favour, not an argument against it. Utopia is a method rather than a plan, a process rather 
than a goal" (Levitas, 2017, p. 9). Achieving utopia is no simple task. On the road to utopia, "I take two steps closer; it goes two steps away. I walk ten steps and the horizon runs ten steps further. As much as I walk, I'll never reach it. What is utopia for? For this: to walk"5 (Galeano, 2001, p. 230). That is the necessary rhetoric of utopian thought.

It is proximate to the definition of rhetoric, understood by Aristotle in the 4th century BC as "the capacity to discover what is adequate in each case in order to persuade" (Aristóteles, 2005). As an example, Aristotle (2005, p. 94) establishes an analogy between rhetoric and medicine, by stating that "it is not the function of medicine to restore a patient to health, but only to promote this end as far as possible; for even those whose recovery is impossible may be properly treated"6. Likewise, utopia and design might help societies in providing adequate responses to chaos. Even if not physically constructed, they still need to be imagined with meaningful spatial traits. Those meanings are attached to the philosophical comprehension within Peircean semiotics, necessarily connected to the context in which they are suggested and perceived in a pragmatic dimension (Morris, 1944). As an analogy, we review Peirce's example of a Fenix which can be referred to by recurrent descriptions and be equally understood by both ends of dialogue, although the creature does not physically exist (Peirce, 2005).

This analogy and the preceding rhetoric illustrate the process of utopian thought that can be related to the design process. To define this view of utopia as a method, we have called it a practical approach. In this sense, it can be related to architectural practices, as a cycle always accompanied by constant critique (Levitas, 2017). A response to chaos via architectural

\footnotetext{
5 Free translation by the author: "Ella está en el horizonte - dice Fernando Birri -. Me acerco dos pasos, ella se aleja dos pasos. Camino diez pasos y el horizonte se corre diez pasos más allá. Por mucho que yo camine, nunca la alcanzaré. ¿Para que sirve la utopía? Para eso sirve: para caminar." (Galeano, 2001, p. 230).

${ }^{6}$ Free translation by the author: "não é função da medicina dar saúde ao doente, mas avançar o mais possível na direção da cura, pois também se pode cuidar bem dos que já não estão em condições de recuperar a saúde" (Aristóteles, 2005, p. 94).
} 
design can be obtained from utopian thinking and the necessary aspects of a communication process that is both contextually meaningful and properly imaginative. That would also serve the understanding of the design process as a complex cycle of communication that encompasses more than just the elaboration of blueprints.

\section{Discussion}

Let us momentarily imagine urban chaos to the scale of a neighbourhood. Architectural perception of a particularly chaotic environment may lead to the recognition of intrinsic spatial patterns, related to physical or metaphysical aspects of the urban reality. Those patterns and their relations can be organised into a type and serve either as a problem or as a reference to new solutions. Meanings can be drawn from those patterns by perception and translated into physical cues, such as narrow streets being more walkable, taller buildings giving the feeling of control or the notion that a park is a place of encounter. The physical cues (configuration) are thus associated with activities (function) and signification (meaning).

A utopia - or a design - would then keep the aspects that are common between this particular neighbourhood and other places (the type) and elaborate the images of new space (a portrait) to suggest transformation. However, all of this will not result in any improvement if the patterns recognised were not significant to the environmental meaning, if the activities are not suitable for that specific social group or if the images used in the suggestion are not understood by the inhabitants of this particular neighbourhood. Although one might say that progress is the realisation of utopias, there is no intrinsic value in the communication processes meaning not all utopias constitute improvement nor are all designs desirable (Wilde, 1891). Nevertheless, utopia and design might together oppose chaos as they can provide an appropriate sense of place and an accurate translation of environmental meaning, explicitly because chaos has no recognisable order 
unless when partially analysed. Chaos can hardly be developed or imagined with intention. Chaos has no meaning unless when defined as the opposite of order and Architecture can assist the imagination of such order once we establish what a "balanced" architectural practice means.

To this end, the role of architects in the search for adequate responses to urban chaos is not to succumb to the economic, political, and social restrictions that the chaotic urban reality might impose, nor to create reproducible solutions that would be replicated regardless of their contexts; it is their role to extract from those real conditions the meanings that constitute a contextual ground for non-verbal communication processes. Pertinent forms must be sought by a meaningful design process. We could say that a design - as utopian thought - should erect a rhetorical mirror to urban phenomena, allowing the present to project the future and looking back from the imagined reflection of the future to criticise the present. If not to physically construct new cities, this practical approach of a continuous critique would at least provide a new and meaningful horizon to our current social formations. That must be the architects' utopia and their response to chaos.

\section{References}

Abusaada, H. and Elshater, A. (2019) 'From chaos to order: articulating urban policies for cities of hardship', in Benna, U. G. (ed.) Industrial and urban growth policies at the sub-national, national, and global levels. Hershey: IGI Global (Advances in Public Policy and Administration), pp. 41-64.

Alexander, C. et al. (2013) Uma linguagem de padrões / A pattern language. 1st edn. Porto Alegre: Bookman.

Aristóteles (2005) Retórica. $2^{\mathrm{a}}$ edição. Edited by M. Alexandre Júnior, P. F. Alberto, and A. do N. Pena. Lisboa: Imprensa Nacional da Casa da Moeda.

Arnheim, R. (1986) El pensamiento visual. Barcelona: Paidós. 
Arnheim, R. (2004) Art and visual perception, a psychology of the creative eye. Los Angeles: University of California Press.

Barthes, R. (1993) 'Semiology and urbanism', in Ockman, J. and Eigen, E. (eds.) Architecture culture, 1943-1968: a documentary anthology. New York: Columbia University/ Rizzoli, pp. 413-418.

Broadbent, G. (1977) 'A plain man's guide to the theory of signs in architecture', Architectural Design, pp. 474-482.

Burch, R. (2018) 'Charles Sanders Peirce', The Stanford Encyclopedia of Philosophy. Winter 201. Metaphysics Research Lab, Stanford University. Available at: https://plato.stanford.edu/archives/win2018/entries/peirce/

Callenbach, E. (2004) Ecotopia: the notebooks and reports of William Weston. 2nd edn. Berkeley: Banyan / Heyday.

Carmona, M. et al. (2003) Public Places, urban spaces: the dimensions of urban design. Oxford: Architectural Press.

Choay, F. (2007) A regra e o modelo: sobre a teoria da arquitetura e do urbanismo. 2nd edn. Casal de Cambra: Caleidoscópio.

Donougho, M. (1987) 'The Language of architecture', The Journal of Aesthetic Education, 21(3), pp. 53-67.

Downton, P. F. (2009) Ecopolis: architecture and cities for a changing climate. Dordrecht: Springer Netherlands (Future City).

Fidalgo, A. (1998) Semiótica: a lógica da comunicação. Covilhã: LABCOM/ UBI.

Galeano, E. (2001) Las palabras andantes. 5th edn. Buenos Aires: Catálogos.

Giaccardi, E. (2003) Principles of metadesign: processes and levels of co-creation in the new design space. Plymouth: University of Plymouth.

Hall, E. T. (1966) The hidden dimension. New York: Doubleday.

Hillier, B. (2007) Space is the machine. London: Space Syntax.

Kohlsdorf, M. E. (1986) Manual de técnicas de apreensão do espaço urbano. Brasilia: Editora da UnB.

Krampen, M. (1991) 'Environmental meaning', Advances in Environment, Behavior, and Design, pp. 231-268. doi: 10.1007/978-1-4684-5814-5_7

Lefebvre, H. (1961) 'Utopie expérimentale: pour un nouvel urbanisme', Revue Française de Sociologie, 2(3), pp. 191-198. doi: 10.2307/3319524 
Levitas, R. (2017) 'Where there is no vision, the people perish : a utopian ethic for a transformed future', CUSP essay series on the Ethics of Sustainable Prosperity. Available at: cusp.ac.uk/essay/m1-5

Mahfuz, E. da C. (2004) 'Reflexões sobre a construção da forma pertinente', Arquitextos (Vitruvius), 45(02). Available at: https://www.vitruvius.com.br/revistas/read/arquitextos/04.045/606

Morris, C. W. (1944) 'Foundations of the theory of signs', International Encycloedia of Unified Science. Chicago: University of Chicago.

Münster, A. (1993) Ernst Bloch - filosofia da práxis e utopia concreta. São Paulo: Unesp.

Netto, V. D. M. (2013) ‘O que a sintaxe espacial não é?’, Arquitextos (Vitruvius), 161(04). Available at: https://www.vitruvius.com.br/revistas/read/arquitextos/14.161/4916

Nöth, W. (1995) Handbook of semiotics. Indianapolis: Indiana University Press.

Peirce, C. S. (2005) Semiótica. $3^{\text {rd }}$ edn. São Paulo: Editora Perspectiva.

Pessoa, D. F. (2006) Utopia e cidades: proposições. São Paulo: Annablume: Fapesp.

Pires, A. (2013) A quinta de recreio em Portugal - Vilegiatura, Lugar e Arquitectura. Lisboa: Caleidoscópio.

Popper, K. (1986) 'Utopia and violence (1947)', World Affairs, 149(1), pp. 3-9.

Portas, N. (1969) A cidade como arquitectura. Lisboa: Livros Horizonte.

Rapoport, A. (1990) The meaning of the built environment: a non verbal communication approach. Beverly Hills: Sage.

Rubinowicz, P. (2000) 'Chaos and geometric order in architecture and design', Journal of Geometry and Graphics, 4(2), pp. 197-207. Available at: https://www.researchgate.net/publication/240759315_Chaos_and_Geometric_ Order_in_Architecture_and_Design

Silva, E. (1998) Uma introdução ao projeto arquitetônico. 2nd edn. Porto Alegre: UFRGS.

Sonesson, G. (2017) 'Mastering phenomenological semiotics with Husserl and Peirce', Semiotics and its Masters, 1. doi: 10.1515/9781501503825-005

Stiny, G. (1980) 'Introduction to shape and shape grammars', Environment and Planning B, 7, pp. 343-351.

Stiny, G. (1981) 'A note on the description of designs', Environment and Planning B, 8, pp. 257-267. 
Tepavcevic, B. and Stojakovic, V. (2012) 'Shape grammar in contemporary architectural theory and design', Facta universitatis - series: Architecture and Civil Engineering, 10(2), pp. 169-178. doi: 10.2298/FUACE1202169T

Vassão, C. A. (2008) Arquitetura livre: complexidade, metadesign e ciência nômade. PhD Thesis. Universidade de São Paulo. Available at: https://www.teses.usp.br/ teses/disponiveis/16/16134/tde-17032010-140902/pt-br.php

Vassão, C. A. (2010) Metadesign: ferramentas, estratégias e ética para a complexidade. São Paulo: Blucher.

Wilde, O. (1891) 'The soul of man under socialism', The Fortnightly Review. New Series, 49(290), pp. 292-319. Available at: https://en.wikisource.org/wiki/ The_Fortnightly_Review/Volume_49/The_Soul_of_Man_Under_Socialism 